Nicoletta De Troia

\title{
On the Edge of the Empire at the End of the Late Roman Period: The Khārga Oasis Sites as a Case Study
}

The Western Oases in Egypt's Western Desert sit at the edge of both the Mediterranean and Egyptian worlds. From north to south, the major oases (Sīwa, Bahriyya, Farāfra, Khārga and Dākhla) map out an arch of cultivated and inhabited areas surrounded by a sandy and barren desert plateau. The presence of natural springs (supported by artesian-water sandstone $)^{1}$ and the fertility of the soil allowed sedentary life to grow and develop in this eastern portion of the Sahara. ${ }^{2}$ However, even though water is obviously a necessary condition for the formation of oases, it is not a sufficient one: ${ }^{3}$ the development and maintenance of an oasis requires a complex equilibrium between environmental, historical, political, and social factors. ${ }^{4}$ The history of the occupation of the Western Oases dates back to the early Old Kingdom and lasted almost continuously for about three millennia until the Late Roman period. Prosperous, linked with the Nile Valley and set deep in the desert, the Egyptian oases "provoke a range of reactions from peoples inhabiting the core [sc. Nile Valley] concern, indifference, inclusion, exclusion, fear, and/or curiosity"5 - the relevant passages in the writings of classical historians and geographers reveal them all. ${ }^{6}$ Without speculating on the lack of detailed descriptions of the oases during the period between Olympiodorus' account and al-Ya'qūbī's, ${ }^{7}$ however, from the last decades of the fourth century on, the oases of Egypt's desert seem to be mostly mentioned as places of exile/banishment sometimes plundered by barbarians. ${ }^{8}$ The association between the place named with the greek word ö $\alpha \sigma \iota$ (often without any further specification) and exile or banishment seems to have become firmer in

\footnotetext{
1 Sampsell (2014).

2 For a concise history of the human occupation of Egypt's Western Desert, see Dunand/Lichtenberg (2008) 59-60 and Sampsell (2014) 148-149.

3 Battesti (2005) 12; see also Garcier/Bravard (2014) 24-36.

4 Lavie/Marshall (2017).

5 Boozer (2013) 278.

6 Wagner (1987) 113-120; Ibrahim (1992). On banishment, see Schwartz (1966) and Vallejo Girvéz (2004).

7 The two accounts have many points in common, such as the description of flourishing soil in the oases; the abundance of water; the distinction between an "inner" and an "outer" (cf. infra). For Olympiodorus (floruit 412-425), see FHG 4.64.33; for al-Ya'qūbī (floruit second half of the $9^{\text {th }}$ century), see $B G A$ 7, 332.

8 See infra.
} 
the texts of Christian writers, ${ }^{9}$ even though deportations to the oasis had most likely been a well-established penalty in Egypt ever since the time of the Roman jurist Ulpian (who died in 228). ${ }^{10}$ The association between the so called ö $\alpha \sigma \iota$ and exile is reflected in the topos of the oases as a remote and isolated land; in some cases, however, correctly identifying the relevant oasis proved impossible, as in the Passio $S$. Artemii of John Monacus (probably John of Damascus) ${ }^{11}$ and the Martyrium S. Artemii of the Byzantine hagiographer Symeon Metaphrastes, ${ }^{12}$ who both placed the oasis where Eugenius and Macarius were exiled in Arabia. Archaeological evidence suggests that from the beginning of the fifth century, the settlements in the oases gradually became more sparsely populated. The waterwheel system ceased to be maintained, and often there are no signs of abandoned buildings being reused.

Early Arabic geographers shed some light on the history of the oases and constitute our main source of information for the early Islamic period. We can have recourse to quite a substantial body of data from both archaeological excavations and literary sources for information on life in the oases in late antiquity. The aim of my paper is to review the main archaeological and literary evidence we currently have on life in the Egyptian oases as the Byzantine era ended and the Islamic one began. Can it be said that life in the oases changed drastically during this period of transition, or did it fundamentally continue as it had been before? I have focused my analysis on the Oasis of Khārga as a representative case study.

9 See e.g. on the exile of Athanasius of Alexandria and some of his followers (c. 357): Athan. Ap. ad Const. 32.25; Id., De fuga 7.8; Socrat. Hist.Eccl. 2.28 (PG 67.273); Theodoret. Hist. Eccl. 2.14; on the exile of two priests, Eugenius and Macarius (362): John of Damascus, PG 96.1288 - 9; Symeon Metaphastes, PG 115, 1187-8; Bidez (1981), 171; on Timasius, the general of Emperor Theodosius I, exiled in the oasis in 396, see Zos. 5.9, Sozomen. Hist.Eccl. 8.7; on the exile of the philosopher Heron: Greg.Naz. Or. 25.14 ( $P G$ 35.1217). About Nestorius, patriarch of Constantinople from 428 to 431 and banished in 435, see Evagr. Hist.Eccl. 1.7, Socrat. Hist.Eccl. 7.34 (PG 67.816), Zonar. 13.22, and Nicephor. 14.35-36 ( $P G$ 146.1173). Banishment to the oasis is also attested in Theophanes' Chronographia: Theoph. Chron. ad a.m. 5982 (Calandion of Antioch in c. 489); Theoph. Chron. ad a.m. 6002 (Dorotheus, monk of Alexandria in c. 509-510); Theoph. Chron. ad a.m. 6005.

10 Dig. 48.22.7.5; Ulp. De off. proc. 10. On the juridical texts, see infra.

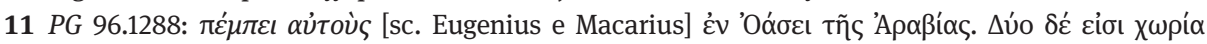

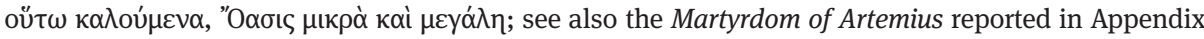
III of Bidez's critical edition of Philostorgius: Bidez (1981) 166 -175. That text seems to be independent of Philostorgius and was probably used by the author of the Passio S. Artemii. On the mention of "oasis," see particularly Bidez (1981) 171, 1l. 11-12 and the notes.

$12 P G$ 115.1187-8. 


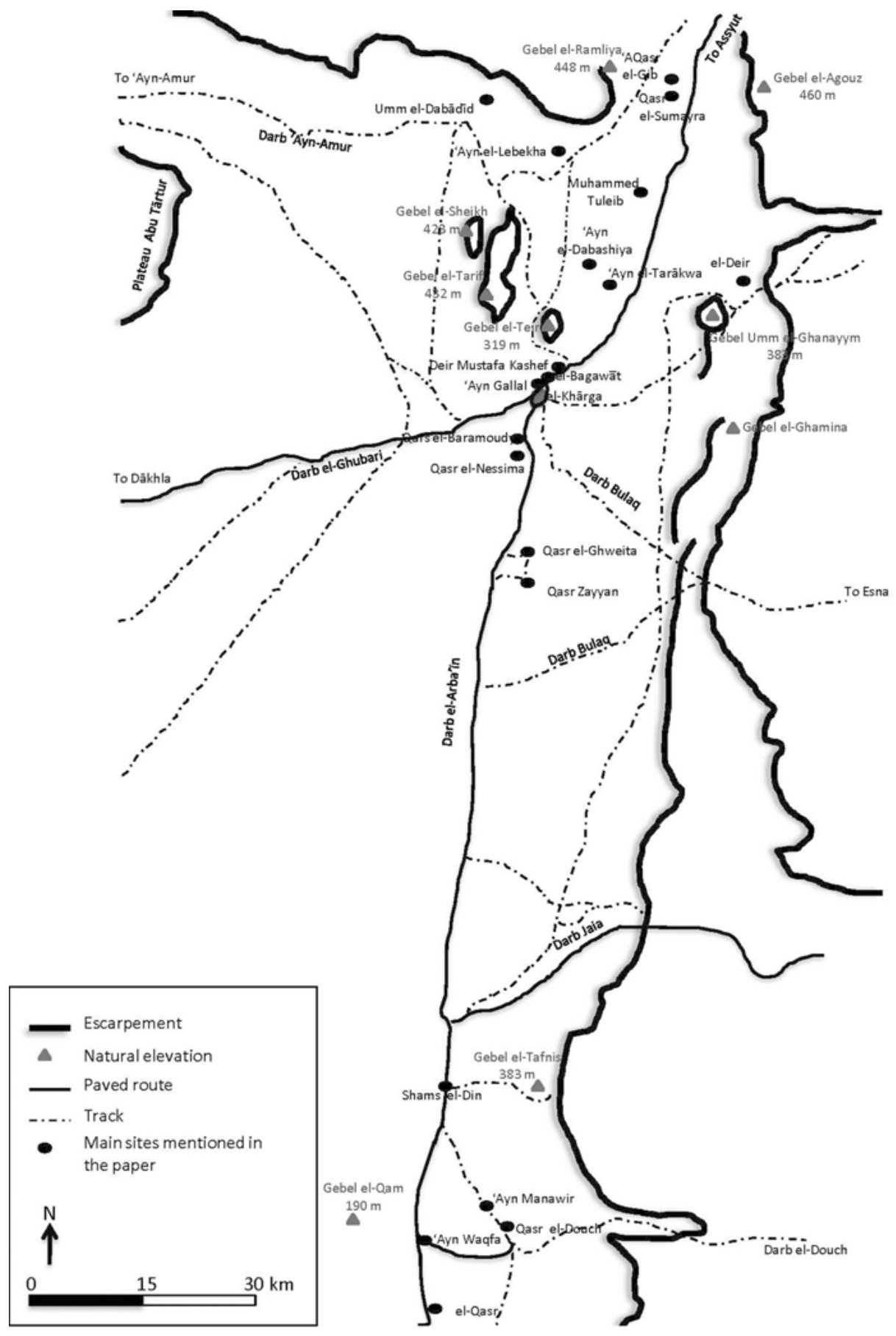

Fig. 6: Map of Kharga Oasis (De Troia). 


\section{The main archaeological features of the Khārga Oasis}

Among the oases of the Western Desert, the Oasis of Khārga is the southernmost and the largest one: its elongated depression measures about $180 \mathrm{~km}$ along the northsouth axis and ranges from 15 to $25 \mathrm{~km}$ in width, resembling, as Wagner wrote, "une véritable vallée parallèle à la Vallée du Nil." "13 Due to its geographical position, the Oasis of Khārga naturally played a key role in the affairs of the Western Desert. ${ }^{14}$ As the nearest oasis to the Nile Valley, it was likely a privileged point of arrival and departure for the routes towards the Nile. ${ }^{15}$ Relatively close to and with good connections to the Oasis of Dākhla, ${ }^{16}$ sited further into the desert, Khārga had also been a convenient stop for travelers along the Dākhla-Nile Valley axis. ${ }^{17}$ From an archaeological point of view, two main features characterized the Oasis of Khārga: an extensive waterwheel system and a chain of late Roman forts. Depending on the geo-morphological characteristics of the oasis depression, two main types of irrigated landscapes were found. The first, at Tell Dūsh, 'Ayn Manāwir, Umm al-Dabādīb, 'Ayn Gib, 'Ayn al-Lebekha, and Qașr al-Zayyān relied on qanawāt. ${ }^{18}$ The second was based on the artesian wells, such as at Al-Deir, Hïbis, and its surrounding area, as per the list of the wells of Hibis. ${ }^{19}$ The existence and the maintenance of the waterwheel system made the development of agriculture possible. The cultivation

13 Wagner (1987) 141.

14 For the Graeco-Roman era, the analysis in Wagner (1987) 141-154 is still valid; Leclant (1950) focused on the routes around Sīwa. The debate on the itineraries along the famous Darb al-Arba'in (the "forty days route") that crosses the Oasis of Khārga from north to south and reaches the land beyond Egypt is still open; see Morkot (1996), Roe (2005/2006), and Ikram (2012).

15 The Darb al-Dūsh runs between Khārga and the Nile Valley and linked Dūsh (the ancient Kysis) to Esna and Edfu (the ancient Latopolis and Apollonopolis Magna); see Gascou et al. (1980) 291. On the desert trails between Dūsh and Aswan (Syene) via the station of Kurkur, see Jackson (2002) 163; on the road between Al-Deir (north-eastern Khārga) to Farshūt and Asyut, see Jackson (2002) 156.

16 There were two routes between Khārga and Dākhla, the Darb al-Ghubārī and the Darb 'Ayn-Amūr. The former, $10 \mathrm{~km}$ longer but easier, was probably preferred by most ancient travelers; see Rossi/ Ikram (2013) 276-277; that route was long at about four days and four nights of walking in a waterless desert, according to a papyrus (M.Chr. 78.5-7) reported in Wagner (1987) 144.

17 Traveling via the Oasis of Khārga allows the difficult path across the arid and waterless Libyan plateau to be avoided. There is only one direct link between the Oasis of Dākhla and the Nile Valley; that route is named Darb al-Tawil (literally "the Long Route"); see Vivian (2000) 108-113.

18 For a general description of the qanawāt water management system, see Goblot (1979); for its diffusion in Northern Africa and Egypt, see De Angeli/Finocchi (2010). In the Oasis of Khārga, the use of the qanawät's sloping tunnels and vertical shafts seems to date back to the Persian period and persist into the Roman era; see Tallet et al. (2011), Wuttmann (2001), Schacht (2003), Gonon (2005), Rossi/ Ikram (2006), and Rossi et al. (forthcoming).

19 Parsons (1971). 
of wheat ${ }^{20}$ as well as of barley, ${ }^{21}$ cotton, ${ }^{22}$ and sesame ${ }^{23}$ in the Oasis of Khārga is thoroughly documented.

The entire Khārga depression is punctuated by several generally well-preserved forts and fortresses. Dated to the Late Roman period and still in use at least until the end of the fourth century, these structures belonged to a larger complex of installations made up of relatively large settlements, cemeteries of various sizes, small industrial areas, and extensive agricultural land.

In the northernmost part of Khārga, one finds the minor forts of Qașr al-Gib and Qașr al-Sumayra. Very similar in shape and architectural features, ${ }^{24}$ the two forts occupy different positions. The former is on a rocky outcrop, whereas the latter is constructed on flat terrain at the end of a line of qanawāt that begins in the vicinity of Qașr al-Gib. Domestic settlements were located to the south and to the south-west of the Qașr al-Sumayra fort, but there were none in the vicinity of Qașr al-Gib. The extensive Gib/Sumayra underground water system covered an area of at least $8.5 \mathrm{~km}$ by $3 \mathrm{~km}$, making it similar in size to the underground water systems at Umm al-Dabādīb and Dūsh. Further to the south, a similar fort exists at Muhammed Tuleib, ${ }^{25}$ now partially covered by sand. In the north-western part of the depression, two rather large installations dated to the fourth century have been found. A gridded settlement surrounds at least three sides (south, west, and north) of what appears to be a square fort at 'Ayn al-Lebekha. ${ }^{26}$ Two springs, one to the north and one to the south, together with four lines of qanawāt provided water to these Roman installations. ${ }^{27}$ The fort

20 O.Douch I 38.4; 39.3; O.Douch I 2.5; and in the church of Shams al-Dīn ostraca where some quantities of grain are mentioned in O.Chams el-Din 1, 2, and 4; 3.1-3.

21 O.Douch I 43.3-4; O.Chams el-Din 2.4; 4.2-3.

22 P.Iand VII 142 and O.Douch II 83, strictly linked to each other, as was noted in Wagner (1987) 292. See also the recent Tallet et al. (2012a).

23 O.Douch III 353.4; O.Chams el-Din 3.4-6.

24 The forts of Qașr al-Gib and Qașr al-Sumayra are $2 \mathrm{~km}$ apart. The first occupies an area of 16x16 m, the latter $11 \times 11 \mathrm{~m}$. Both forts are made up of mud-brick for the most part and consist of a thick enclosure wall with a single entrance to the south. There are buttresses at the four corners and stairs left of the entrance. Hidden by the upper part of the wall, a passage runs right around each fort; see Ikram/Rossi (2004).

25 Ikram/Rossi (2002-2003).

26 The 'Ayn al-Lebekha fort has a central court surrounded by vaulted rooms similar to the ones of Umm al-Dabādīb and Qașr al-Gib. Narrow passages reach the chambers at the four corners. While no traces of a staircase have survived at 'Ayn al-Lebekha, it is likely that stairs were placed in a vertical space north of the gate. On the east side of the fort, no substantial remains of buildings were found during the survey; see Rossi/Ikram (2010).

27 At 'Ayn al-Lebekha, as well as at Umm al-Dabādīb, Qașr al-Gib and Qașr al-Sumayra, dating the qanawāt system is not easy without an extensive excavation. The possibility that the underground aqueducts date back to the Persian period cannot be ruled out. However, no evidence of a largescale Persian settlement was discovered during the surveys. As such, for the moment it seems acceptable to date the qanawāt tunnels to the Roman period. 
at Umm al-Dabādīb ${ }^{28}$ is surrounded by a large built up area (c. 100x100 m) enclosed by a thin mud-brick perimeter wall. The walls are c. $4 \mathrm{~m}$ high and one mud-brick thick. ${ }^{29}$ At Umm al-Dabādỉb, two other settlements have been registered, one to the north and a smaller eastern one. The first measures about $150 \mathrm{~m}$ east-west and $400 \mathrm{~m}$ north-south, and the latter approximately $75 \mathrm{~m}$ east-west and $125 \mathrm{~m}$ northsouth. Both are north-south oriented and have their own lines of underground aqueducts. The two fortified structures at Qașr al-Nessima and Qașr al-Baramūdī, ${ }^{30}$ in the central part of Khārga, are very similar. The legionary fortress of Al-Deir ${ }^{31}$ is located in the eastern part of Khārga. The mud-brick structure is almost square (59x58 m) and features rounded towers at the corners and, less prominently, also along the curtain walls. This type of structure corresponds to the architecture of the forts at Qarat al-Ṭüb in the Oasis of Bahriyya and at Al-Qașr in the Oasis of Dākhla. In the central part of Khārga, three more sites belonging to the Roman period exist: the walled temple of Nadura, on a hill in the vicinity of Hībis, ${ }^{32}$ Qașr al-Ghuwayța, and Qașr al-Zayyān, which all consist of mud-brick enclosures surrounding stone temples. The southern part of the Khārga depression is dominated by a large quadrangular building known as the "fort" of Dūsh. Dūsh is a large and stratified site, probably occupied during the Persian period and still inhabited at the middle of the fifth century. As per the results of the French excavation, "la vie de Douch s'explique essentiellement par la mise en valeur d'un terroir riche en potentialités agricoles." ${ }^{33}$ Military units were garrisoned at Dūsh only from the fourth century onwards. ${ }^{34}$

The reuse of the mud-brick enclosure walls for the purposes of garrisoning troops dates back to the same time. Originally, these walls were probably built to protect the religious complex of Dūsh. ${ }^{35}$ To summarize, as reported by Reddé, Dūsh "ont pu servir de points d'appui à un maillage défensive de l'oasis [sc. Khārga], au BasEmpire, mais sans constituer pour autant de véritables forteresses construites par or pour l'armée." ${ }^{36}$ The presence of military units, at least during the fourth century,

28 The fort has a square plane (c. $15 \times 15 \mathrm{~m}$ ) with two rectangular towers on the southern side. The entrance is from the south and the doorway consists of a stone lintel inserted under a mud-brick arch as in the forts of Qașr al-Gib and Qașr al-Lebekha; see Rossi/Ikram (2006).

29 Rossi/Ikram (2006); for the fort and fortified settlement, see Rossi (2000).

30 The two forts of Qașr al-Nessima and Qașr al-Baramūdī have not yet been studied, but in terms of their general layout, they strongly resemble Qașr al-Lebekha and Umm al-Dabādīb with their central buildings surrounded by gridded settlements; see Rossi/Magli (2019).

31 Brones/Duvette (2007).

32 The temple of Nadura measures approximately $12 \times 21 \mathrm{~m}$. The entrance is on the east side, and there are remains of bastions to the north of the gateway. The site was described by Naumann (1939) $10-13$.

33 Reddé (1996) 77-78.

34 During the Principate, the garrisons have been not documented in Dūsh. The earliest mention of soldiers at Dūsh dates to 302 (P.Grenf. 74); see Reddé (2007) 428.

35 Reddé et al. (2004).

36 Reddé (1999) 382. 
was also established at Hībis. The Notitia Dignitatum ${ }^{37}$ mentions a cavalry unit (ala I Abasgorum) in the Great Oasis at Hībis. Furthermore, some ostraca from Dūsh men-

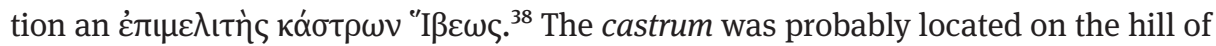
Nadura (only $2 \mathrm{~km}$ south-east of Hìbis). ${ }^{39}$ The mud-brick enclosure walls of the temple, while originally not built for military purposes, could have functioned as a fort.

The function of the forts and fortresses of Khärga is still the subject of scholarly debate. Even though the presence of military units is attested in Khārga during the late Roman Period, it appears to have been modest in size. ${ }^{40}$

Judging by the main road axes that spanned the depression, the forts seem to have been located taking the obligatory routes into and out of Khārga into consideration. The role the forts played was most likely to have been that of governance, as well as protection of the settlements, aqueducts, cultivated crops, and crossroads. The forts were not isolated structures, but part of a far more complex permanently populated settlement. Khārga most likely functioned not only as a military outpost, but also as a borderland.

The well-documented presence of Christian communities in Khārga yields up even more detail on the life in the oasis. Christian worship ${ }^{41}$ began to spread in Khārga during the third century and was well-established there from the fourth to the sixth centuries, as John Moschus relates. ${ }^{42}$ The results of Cruz-Uribe's studies on the Christian archaeological evidence unearthed in Khārga show that Christian churches were built in the same areas as the ancient pagan temples of the early Byzantine period. The fourth-century church at Hìbis, for instance, was built adjacent to the temple of Seth and attached to the temple wall, with doors side by side. Similarly, at 'Ayn al-Tarākwa, a church also dated to the fourth century was sited just ahead of the entrance to the temple's sanctuary. ${ }^{43}$ Moreover, at Dūsh, Umm al-Dabādīb, and Al-Deir, the Christian churches seem to represent the only differentiated public spaces in the urban area of the settlement. Evidence of Christian communities, mostly dated to the fourth or fifth centuries, was also found at 'Ayn al-Turba, only $500 \mathrm{~m}$ north of Hībis. Buildings which have been identified as monasteries have been found at Deir al-Bagawāt, Deir Mușțafā Kāshif, ${ }^{44}$ and 'Ayn Gallāl (c. 1.5 km south). Hermitages were located at Gebel al-Tayr and in the vicinity of Umm al-Dabādīb. The Greek

37 Not.Dig.Or. 31.55.

38 O.Douch III 216.6; III 220.2-3; IV 397.

39 Bagnall (2001).

40 Reddé (1991); see also recently Tallet et al. (2012b) and Rossi (2013).

41 Ghica (2012) 191-195.

42 John Moschus, Pratum spirituale 123 = PG 87.1975-2978. The Byzantine author mentions the presence of a group of monks who inhabited the oasis during the second half of the sixth century and suffered some raids no later than the time of Emperor Tiberius II (578-582).

43 Ikram/Rossi (2007) 169-172 and plan p. 173.

44 A five-story building (c. 24x28 m) with a high wall was found at the Deir Mușțafā Kāshif site. It was built around a rock tomb located in the lower level. The tomb was interpreted by Müller-Wiener (1963) as an old tomb reused as the dwelling-place of a hermit. 
ostraca of 'Ayn Waqfa ${ }^{45}$ and the Greek graffiti of Shams al-Dinn ${ }^{46}$ confirm the existence of flourishing Christian communities in both of these settlements.

\section{From Olympiodorus' account to the descriptions of the early Arabic geographers}

The account of Olympiodorus, now known only in the abridged form compiled in the ninth century by the lexicographer Photius, describes the great prosperity of the

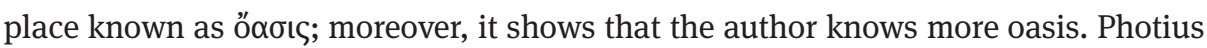
in fact reports that according to Olympiodorus the oases are three in number: "two

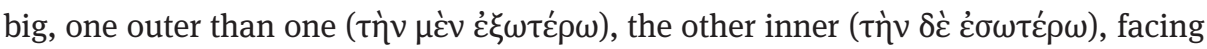
each other and separated by 100 miles - and a smaller third one, much more distant from the two."47

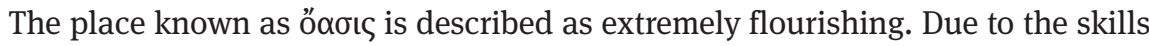
of their inhabitants as well-diggers, the water supply system took in some very deep wells (200 or 300 cubits in depth, or maybe even 500 ) that enhanced the productivity of the soil: "The trees are full of fruit, the wheat is of the best quality and whiter than snow; barley is even sown twice a year and millet is always sown three times." 48 According to Olympiodorus the oasis was originally an island surrounded by the sea, as seems to be confirmed by the great quantity of sand and the numerous fossil shells

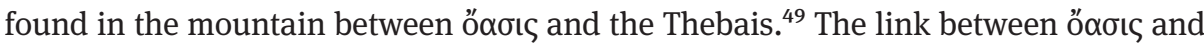
the Thebais seems to suggest that so-called $\dot{\eta}$ ö $\alpha$ os can be likely identified with the Oasis of Khārga. ${ }^{50}$

In Olympiodorus' account, there is no reference to banishments to the oases, but from some juridical texts, it is possible to infer that that form of punishment had been well-established at least since the time of the Roman jurist Ulpian (died 228),

45 Three Christian priests (Psillis, Mousaios, and Chrèstos) are known from the ostraca and named as taxpayers or intermediaries (for Psillis, see O.Waqfa 3.1-2; 46.1; 19.1; for Mousaios, O.Waqfa 19.6-7; for Chrèstos, O.Waqfa 28.2-3; 41.2).

46 Graff.Chams el-Din 1-67 were published in Wagner (1987) 26-44; see in particular the graffiti of Flavius Makarios, the Christian soldier of the Maurii Scutarii (Graff.Chams el-Din 11) and the one inscribed by order of the princeps of Mounesis (ancient toponym of Shams al-Din) and of the chief of curiales for Kyros son of Guanēs, his son Eudoxios (soldier of the legion of Hermopolis), his wife, and his children - all of them are Christians (Graff.Chams el-Din 49).

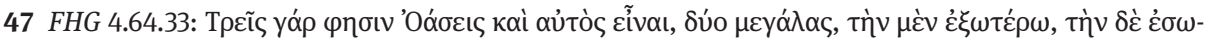

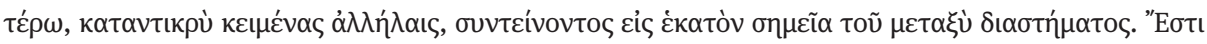

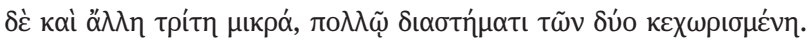

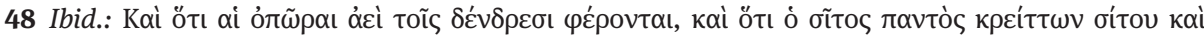

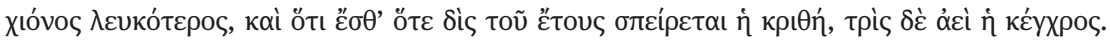

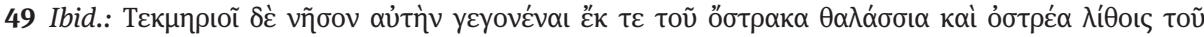

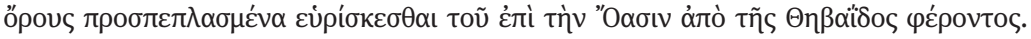

50 Henry (1959) 180 n. 3. 
who mentioned relegatio in oasin; that was a particular kind of relegatio in insulam used in the provincia of Egypt. ${ }^{51}$ In a law dating to 409, another form of banishment to the oasis is mentioned, the oasena deportatio; that particular form of exilium was to be imposed on the accomlices to damage of the Nile levees. ${ }^{52}$ Moreover, a later law

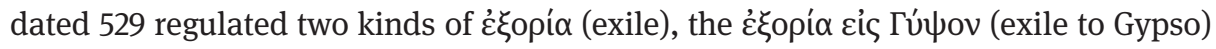

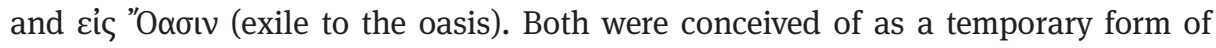
exile (from six months to one year) and the law decreed that only the authorities of Alexandria and the Thebais could impose those penalties. ${ }^{53}$ In spite of the differences between the relegatio in oasin and oasena deportatio, ${ }^{54}$ both forms of punishment represent very specific Egyptian penalties. Christianity seems to emphasize the

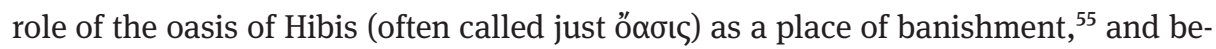
tween the beginning of the fifth and the eighth centuries, as far as is known, ecclesiastical writers and Byzantine historians mention the Egyptian oasis almost as a place of exile.

Moreover, from the beginning of the fifth century, there are fewer and fewer signs of the Khārga sites being occupied. Excluding the possibility of our failure to recognize later settlements archaeologically (no evidence suggesting our perception was flawed could be detected), the contraction and gradual abandonment of Khārga is still the subject of debate; if the population moved out, it is still not clear where they went.

Scholars have hypothesized that the oasis may have been abandoned due to either climatic change or to an increasing lack of security. As for climatic change, the desertification of an arid environment is a lengthy process, and a sudden dramatic decrease in the water supply seems unlikely. Sudden natural disasters can be exclud-

51 The second-century Roman jurist speaking about relegatio in insulam said that est quoddam genus quasi in insulam relegationis in provincia Aegypto in oasin relegare (Dig. 48.22.7.5; Ulp. De off.proc. 10). 52 Cod.Th. 9.32.1 (409): "Impp. Honorius et Theodosius aa. Anthemio praefecto praetorio. Si quis posthac per Aegyptum intra duodecimum cubitum fluminis Nili ulla fluenta de propriis ac vetustis usibus praeter fas praeterque morem antiquitatis usurpaverit, flammis eo loco consumatur, in quo vetustatis reverentiam et propemodum ipsius imperii adpetierit securitatem: consciis et consortibus eius oasenae deportationi constringendis, ita ut numquam supplicandi eis vel recipiendi civitatem vel dignitatem vel substantiam licentia tribuatur. Dat. $x$ kal. octob. Constantinopoli Honorio VIII et Theodosio III aa. conss".

If the penalty imposed to accessories to the damage of the Nile levees was exile, the one for the harbor robbers was even more severe, they in fact shall be burned to death.

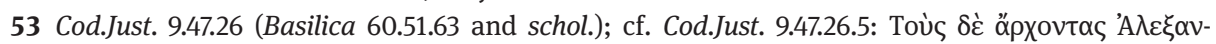

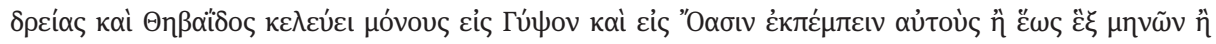

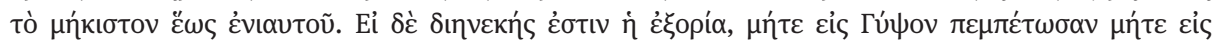

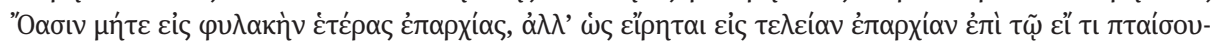

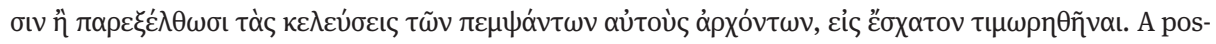
sible interpretation could be that the authorities of Alexandria and the Thebais shall impose respec-

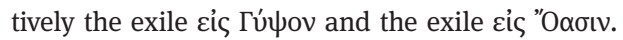

54 See Sánchez-Moreno Ellart (2013) on the difference between deportatio and relegatio.

55 See the aforementioned Schwartz (1966) and Vallejo Girvéz (2004). 
ed, as there is no archaeological evidence of any sort of violent event. It seems that the inhabitants abandoned their homes over a period of time. Nomadic attacks against the oasis seem to have become more frequent and more challenging, for instance the attack on the capital of the Khārga Oasis in $373^{56}$ or the incursion in $450,{ }^{57}$ when Hỉbis was partially sacked and destroyed. Judging these nomadic incursions by their apparent objectives, they are perhaps best defined as raids, rather than as directly targeted attacks on the oasis and its population. While these nomadic attacks tended to be brief and sudden, they could have complicated the management of the area. Moreover, the above-mentioned Byzantine author John Moschus reported that a group of monks who lived in Khārga were taken prisoner by some marauders called Mazikes. ${ }^{58}$ The episode was recorded at the time of Tiberius II Constantius (578-582), when Moschus journeyed to the Oasis of Kharga and met Abba Leo. The old monk told Moschus about the marauds of Mazikes, which probably had occurred during his youth. It is not possible to know exactly how often such episodes happened, but John Moschus' account likely sheds light on a general perception of growing insecurity in the Oasis of Kharga; ${ }^{59}$ similarly also the rest of Egypt's Western Desert seems to have become even more frightening from the fifth century. Monasteries, such as that of Sketis, suffered continued sacks, ${ }^{60}$ and a northern oasis not far from Oxyrhynchos - probably the oasis of Bahriyya - became known as the oasis inhabited by Mazikes, ${ }^{61}$ often desbribed as violent and rude people. ${ }^{62}$

However, taking into consideration reports by Arabic geographers, it would seem that life in the oases did not completely disappear at the end of the Byzantine era. As far as we know, the earliest mention of al-wāha (Arabic for "the oasis") is in a passage of al-Fazārī's work (from the end of the eighth century), which was cited in AlMas 'ūdī's Book of Golden Meadows. ${ }^{63}$ The context is a list of countries and al-Fazārì's words comprise only the toponym al-wāha and the dimension of the place named, 60 x 40 parasanges (c. 360 x $240 \mathrm{~km}$ ). No further details are offered, and the location of the place called al-wäha remains uncertain. ${ }^{64}$ More detailed information is found in al-Ya'qūbì's Kitāb al-Buldān, ${ }^{65}$ dating back to the second half of the ninth century. The early Arabic historian and geographer combines political and administrative aspects, ethnographic notes, and itinerary descriptions. The Egyptian place called al-

56 Wagner (1987) 396-397.

57 Winlock (1936) 48-9; Wagner (1987) 399.

$58 P G$ 87.3, coll. $2976-8$.

59 Bagnall (2001).

60 See the studies of Evelyn White (1932) 154-167 and more recently Wipszycka (2009) 624-627.

61 PL 73, col. 1010; see also Pall., Dial. de vita Joh.Chrys. 20.

62 See e.g. Cass. Conl. 2.6.1-3; PL 73, col. 841.

63 Al-Mas' 'ūdī, Les Prairies d'Or 4.62, ed. Barbier De Meynard (1914), 39. For more on the Arabic astronomer al-Fazārī, see Samsó (2007).

64 Décobert (1982) 97.

$65 B G A 7,332$. 
wāḥāt $t^{66}$ (literally "the oases”) can be reached, al-Ya'qūbī reports, after a six-day journey along a desert and mountain route starting from Abshāya (Abydos). Al-wāḥat consists of two parts: al-wāha al-khārija ("the exterior oasis"), characterized by the presence of fortifications, cultivated fields, an abundance of water, palm trees and other types of fruitful trees, vines, and rice fields, and al-wāha al-dākhila ("the interior oasis"), which also includes the oasis of Farāfra. ${ }^{67}$ The two expressions al-wāha

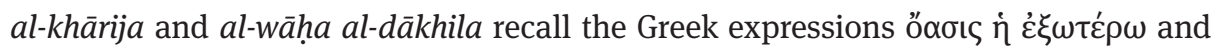

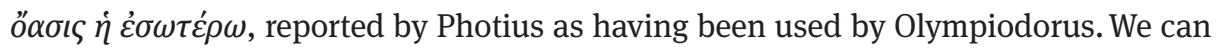
compare the detailed account by Olympiodorus of the ö $\alpha \sigma ı$ with Ya'qūbì's description of al-wāha al-khārija. In both passages, the oasis seems to be rich in water, fertile, and connected to the rest of Egypt by a route running in an east-west direction where the presence of human life is well marked. The new element arising in Ya'qūbì's account is the presence of fortifications. ${ }^{68}$

More than ten years later, a further mention of the Egyptian oases occurs in Ibn al-Faqīh's Kitāb al-Buldān, survived only in abridged form. The passage relating to the oasis. ${ }^{69}$ Is part of a description of an itinerary from the country of Ghāna ${ }^{70}$ (depicted as a region where gold grows in the sand like carrots and is plucked at sunrise $^{71}$ ) to the land of Egypt. Along that itinerary, the first three stops are identified with the names of the peoples who lived in the regions along the way, the Kawkaw, the Maranda, and the Marāwa. ${ }^{72}$ After this, and before reaching Egypt proper, comes a stop named wāḥāt miṣr at Malsāna, identified with the Gilf Kabir plateau. The jux-

66 The occurrence al-wāhāat is attested only in that passage of Ya 'qūbì’s Kitāb al-Buldān. Referring to a very specific place, Décobert (1982) 98 argued that Ya'qūbī used the name al-wāhāt as a toponym. 67 "From Abshāya, you travel to the oases through desert wastes and rugged mountains for six stages. Then you proceed to the Outer Oasis. It is a country with forts, cultivated fields, bubbling springs, flowing water, date palms, different varieties of trees, vines, rice fields, and more; then to the Inner Oasis. It has a city called Al-Farfarūn with a mixed population of Egyptians and others" - English translation Gordon et al. (2017) 170.

The city of Al-Farfarūn is probably the modern village Al-Qașr in the oasis of Farāfra, see Cornu (1985) 100. The oasis of Farāfra in the account of the early Arabic Geographers is usually reckoned as part of Dākhla Oasis; see Graefe (1927).

68 As far as we know, the Greek and Latin authors did not refer to the presence of any kind of fortified structures in Khārga nor in the other oases. An exception seems to be a passage by Malalas, even though there is no explicit mention of the oases proper. The sixth-century author mentions that Emperor Diocletian "built fortresses on the limes from Egypt to the Persian borders and stationed limitanei in them and he appointed duces for each province to be stationed further back from the fortresses with a large force to ensure their security" (Chronographia 12.40).

$69 B G A 5,68$.

70 Cornevin (1965a); Triaud (1999).

$71 B G A$ 5, 87: "In the country of Ghāna gold grows in the sand as carrots do, and is plucked at sunrise." As far as we know, it seems that that is the first occurrence of that metaphor; English translation and commentary Levtzion/Hopkins (1981) 26.

72 The name Kawkaw is used to refer to Gao; see Cornevin (1965b). The name Maranda seem to refers to the people of Arinda, who inhabited the Air, and the people of Marāwa have not yet been firmly identified; see also Décobert (1982) 101. 
taposing of the two toponyms "oases" and "Egypt" in the expression wāhāt mișr (from grammatical point of view an idāfa) evidences the strong tie between the two. As the first "Egyptian" stop of the trans-Saharan itinerary between Ghāna and Egypt, the wāhāt miṣr is both part of Egypt and on its borderland, and functions as a sort of gateway. ${ }^{73} \mathrm{Al}$-wāḥăt was also described as a borderland by Al-Ișțakhrī. The tenth-century Arabic geographer reports that the journey between the oases and Upper Egypt takes three days and that a desert plain links the oases to Nubia. ${ }^{74}$

In comparison with al-Ya'qūbì's description of the products of al-wāhāt, the account of Al-Ișțakhrī seems to show a rather different picture. Al-Ișțakhrī narrates that all signs of human presence have completely disappeared from al-wāh also that once the region named al-wāhăt was cultivated and was rich in water, fruit trees, and villages, but that by his time, even though the fruit continued to be copious, the animals were running wild..$^{75}$ Is such great change plausible in the only approximately fifty years between Al-Ișțakhrī's description and al-Ya'qūbī’s?

According to Décobert, a description of al-wāhāt in these terms is plausible only if matched with the definition of the western frontier of Egypt given by al-Ișțakhrī. The western frontier of Egypt runs from the region of Barqa and Alexandria across a desert plain, then it reaches al-wāḥāt and finally terminates in Nubia. ${ }^{76}$ In Al-Ișțakhrì's account, the place named al-wāhāt is a borderland between Egypt and the land beyond. Being a frontier, al-wāhāt may be logically considered a "wild" land.

Moreover, Al-Mas ${ }^{\mathrm{u}} \mathrm{d}_{\overline{\mathrm{i}}}{ }^{77}$ reports that the oases were under the rule of a king of the oases, a man from the Lawāta tribe, in 943/944. ${ }^{78}$ Politically speaking, Al-Mas'ūdì describes the oases as falling within Egypt's district, but equipped with a certain degree of independence, as signified by the existence of a "king of the oases." Independence here can be intended to signify at least a degree of self-sufficiency from a military and economic point of view. The relations between the Egyptian governors and the people of Lawāta could not always have been peaceful, and this ambivalence, Décobert believed, ${ }^{79}$ can be perceived in the description of al-wāh $\bar{a} t$ as uninhabited and wild land or as the ultimate flourishing and inhabited part of Egypt. Ibn Hawqal's account of the oases dates to the end of the tenth century ${ }^{80}$ and recalls both al-Ya'qūbỉ's and Olympiodorus' descriptions above. Ibn Hawqal describes the oases as divided into two parts, the interior and the exterior (in three-days distance from each other). Furthermore, the oases appear to be uninhabited and under the control of the Lawāta tribe (as in Al-Mas'ūdī's account).

73 Décobert (1982) 104-105.

$74 B G A 1^{2}, 10-11$.

$75 B G A 1^{2}, 52$.

76 Ibid.

77 Al-Mas' 'ūdī, Les Prairies d'Or 3.33, ed. Barbier De Meynard/Courteille de (1917), 50 - 52.

78 Lewicki (1986).

79 Décobert (1982) 111.

80 BGA 2 $2^{2}, 153-156$. 
The tenth-century author reports some new information regarding the routes that pass through the oases. These routes across the desert link al-wāhāat to the Maghreb and the land of the black people. Crossing the desert frontier of Egypt, another itinerary starts from Upper Egypt and reaches the oases, and then finally the region of Nubia. Moreover, the author specified that the route between Egypt and Ghāna was not in use at this time.

Ibn Hawqal's description of all these routes, included the one from Egypt to Ghāna not yet in use, can possibly echo the importance that the trans-Saharan routes were acquiring during the entire early Islamic period. Due to the geographical position it occupied and its proximity to the Nile Valley, al-wāhāt played both the role of Egypt's borderland and that of a gateway to Egypt for travelers along the trans-Saharan desert itineraries.

Comparing the network of routes across the desert between the Byzantine and the early Islamic period, the scale seems to have drastically shifted. The presence of trans-Saharan routes is not documented for the periods before the Islamic era. However, in both Byzantine and early Islamic Egypt, the oases were a borderland considered as the last Egyptian stage. The Oasis of Khārga, the "exterior oasis" both in Greek and in Arabic, seems to at least maintain continuity from an onomastic point of view. This can be thought of as a trait d'union between the Byzantine and the Islamic era.

\section{Abbreviated non-papyrological sources}

$B G A=$ Michael J. De Goeje (ed.), Bibliotheca Geographorum Arabicorum, Leiden 1890-1894.

$F H G=$ Karl Müller, Theodor Müller, and Victor Langlois (eds.), Fragmenta Historicorum Graecorum, Paris 1841-1873.

FGrH = Felix Jacoby (ed.), Die Fragmente der griechischen Historiker, 15 vols., Berlin, Leiden $1923-1958$.

PG = Jacques P. Migne (ed.), Patrologiae Cursus Completus Series Graeca, 161 vols., Paris $1856-1866$.

$P L=$ Jacques P. Migne (ed.), Patrologiae Cursus Completus Series Latina, 221 vols., Paris, 18441855.

\section{Bibliography}

Bagnall (2001): Roger S. Bagnall, “The camp of Hibis”, in: Traianos Gagos and Roger S. Bagnall (eds.), Essay and Texts in Honor of J. David Thomas (Amercian Studies in Papyrology 42), Oakville, 3-9.

Barbier De Meynard (1914): Casimir Barbier De Meynard (ed.), Les Prairies d'Or 3. Texte et traduction, Paris, 1914.

Barbier De Meynard/Courteille de (1917): Casimir Barbier De Meynard, Pavet de Courteille (eds.), Les Prairies d'Or 3. Texte et traduction, Paris, 1917. 
Battesti (2005): Vincent Battesti, Jardins au désert. Évolution des pratiques et savoirs oasiens. Jérid tunisien, Paris.

Bidez (1981): Joseph Bidez, Philostorgius. Kirchengeschichte, mit dem Leben des Lucian von Antiochien und den Fragmenten eines arianischen Historiographen (Die griechischen christlichen Schriftsteller der ersten drei Jahrhunderte 21), $3^{\text {rd }}$ ed. revised by Friedhelm Winkelmann, Berlin.

Boozer (2013): Anna L. Boozer, "Frontiers and borderlands in imperial perspectives. Exploring Rome's Egyptian frontier”, in: American Journal of Archaeology 117.2, 275-292.

Brones/Duvette (2007): Sophie Brones and Catherine Duvette, "Le fort d'El-Deir, oasis de Kharga. 'État des lieux' architectural et archéologique”, in: Bulletin de l'Institut français d'archéologie orientale 107, 5-41.

Cornevin (1965a): Robert Cornevin, “Ghāna”, in: Encyclopaedia of Islam², vol. II, 1001-1003.

Cornevin (1965b): Robert Cornevin, “Gao”, in: Encyclopaedia of Islam², vol. II, 976-978.

Cornu (1985): Georgette Cornu, Atlas du monde arabo-islamique à l'époque classique IXe-Xe siècles, Leiden.

De Angeli/Finocchi (2010): Stefano De Angeli and Stefano Finocchi, "Origine e diffusione dei canali idrici drenanti (qanat/foggara) in Africa settentrionale in età antica", in: Bolletino di Archeologia online, 39-52.

Décobert (1982): Christian Décobert, “Un espace-prétexte. Les oasis d’Égypte vues par les géographes arabes", in: Studia Islamica 55, 95-114.

Dunand/Lichtenberg (2008): Françoise Dunand and Roger Lichtenberg, Oasis égyptiennes. Les îles des Bienheureux, Arles.

Evelyn White (1932): Hugh Gerrard Evelyn White, The Monasteries of the Wâdi 'n Natrun. Part II: The History of the Monasteries of Nitria and of Scetis (Publications of the Metropolitan Museum of Art Egyptian Expedition 7), New York, 1932.

Garcier/Bravard (2014): Romain Garcier and Jean-Paul Bravard, "La durabilité des oasis. Aperçus de géographie historique à partir du cas de l'oasis de Kharga, Egypte”, in: Anaïs Marshall et al. (eds.), Actes du colloque "Oasis dans la mondialisation: ruptures et continuités", 16-17 décembre 2013, Paris, Paris, 29-36.

Gascou et al. (1980): Jean Gascou et al., "Douch. Rapport préliminaire des campagnes de fouilles de l'hiver 1978/1979 et de l'automne 1979", in: Bulletin de l'Institut français d'archéologie orientale $80,287-345$.

Ghica (2012): Victor Ghica, "Pour une histoire du christianisme dans le désert occidental d’Égypte”, in: Journal des Savants 2.1, 189-280.

Goblot (1979): Henri Goblot, Les Qanats, Une technique d'acquisition de l'eau (Industrie et Artisanat 9), Paris.

Gonon (2005): Thierry Gonon, “Les Qanats d’Ayn-Manâwîr (Oasis de Kharga, Egypte). Techniques de creusement et dynamique de l'exploitation d'une ressource épuisable de la première domination perse au II siècle de l'Ère Commune", in: Internationales Frontinus-Symposium “Wasserversorgung aus Qanaten: Qanate als Vorbilder im Tunnelbau”, 2.-5. Oktober 2003, Walferdange, Luxemburg, 39-57.

Gordon et al. (2017): Matthew S. Gordon et al. (eds.), The Works of Ibn Wāḍị al-Ya'qūbī. An English Translation. vol. I, Leiden and Boston.

Graefe (1927): Erich Graefe, "al-Farāfra”, in: Encyclopaedia of Islam ${ }^{1}$.

Henry (1959): René Henry (ed.), Photius. Bibliothèque. I: Codices 1-84, Paris.

Ibrahim (1992): Muhammad Abboudy Ibrahim, "The Western Desert of Egypt in the classical writings of the Roman era", in: Giovanni Pugliese Carratelli et al. (eds.), Roma e l'Egitto nell'Antichità classica. Atti del I Congresso Internazionale Italo-Egiziano, Cairo, 6-9 Febbraio 1989, Roma, 209-217. 
Ikram (2012): Salima Ikram, “Wanderers in the desert. The North Kharga Oasis Survey's exploration of the Darb 'Ain Amur”, in: Roger S. Bagnall, Paola Davoli, and Colin A. Hope (eds.), The Oasis Papers 6. Proceedings of the Sixth International Conference of the Dakhleh Oasis Project (Dakhleh Oasis Project Monograph 15), Oxford, 9-18.

Ikram/Rossi (2002-2003): Selima Ikram and Corinna Rossi, "Surveying the North Kharga Oasis", in: Kmt. A Modern Journal of Ancient Egypt 13.4, 72-79.

Ikram/Rossi (2004): Selima Ikram and Corinna Rossi, “North Kharga Oasis Survey 2001-2002. Preliminary report: Ain Gib and Qasr el-Sumayra", in: Mitteilungen des Deutschen Archäologischen Instituts 60, 69-92.

Ikram/Rossi (2007): Salima Ikram and Corinna Rossi, “North Kharga Oasis Survey 2004. Preliminary report: Ain el-Tarakwa, Ain el-Dabashiya and the Darb Ain Amur”, in: Mitteilungen des Deutschen Archäologischen Instituts 63, 165-182.

Jackson (2002): Robert B. Jackson, At Empire's Edge. Exploring Rome's Egyptian Frontier, New Haven and London.

Lavie/Marshall (2017): Emilie Lavie and Anaïs Marshall, "Introduction”, in: Emilie Lavie and Anaïs Marshall (eds.), Oases and Globalization. Ruptures and Continuities (Springer Geography), Cham, ix-xv.

Levtzion/Hopkins (1981): Nehemia Levtzion and John F. P. Hopkins, Corpus of Early Arabic Sources for West African History, Cambridge.

Lewicki (1965): Tadeusz Lewicki, “Lawāta”, in: Encyclopaedia of Islam², vol. V, 694-698.

Leclant (1950): Jean Leclant, "Per Africae sitientia. Témoignages des sources classiques sur les pistes menant à l'Oasis d'Ammon", in: Bulletin de l'Institut français d'archéologie orientale 49, $193-253$.

Miquel (1967): André Miquel, La géographie humaine du monde musulman jusqu'au milieu du XIe siècle, Paris and The Hague.

Morkot (1996): Robert G. Morkot, "The Darb el-Arbain, the Kharga Oasis and its forts, and other desert routes”, in: Donald Bailey (ed.), Archaeological research in Roman Egypt. Proceedings of the Seventeenth Classical Colloquium of the Department of Greek and Roman Antiquities, British Museum, Held on 1-4 December 1993 (Journal of Roman Archaeology suppl. 19), 82-94.

Müller-Wiener (1963): Wolfgang Müller-Wiener, “Christliche Monumente im Gebiet von Hibis (el-Kharga)", Mitteilungen des Deutschen Archäologischen Instituts Kairo 19, 121-140.

Naumann (1939): Rudolf Naumann, “Bauwerke der Oase Khargeh”, in: Mitteilungen des Deutschen Instituts für ägyptische Altertumskunde in Kairo 8, 1-16.

Parsons (1971): Peter J. Parsons, "The wells of Hibis", in: The Journal of Egyptian Archaeology 57, $165-180$.

Roe (2005/2006): Alan Roe, “The old 'Darb al Arbein' caravan route and Kharga Oasis in antiquity", in: Journal of the American Research Center in Egypt 42, 119-129.

Reddé (1991): Michel Reddé, "A l'ouest du Nil. Une frontière sans soldats, des soldats sans frontière", in: Valerie A. Maxfield and Michael J. Dobson (eds.), Roman Frontier Studies 1989. Proceedings of the $X^{\text {th }}$ International Congress of Roman Frontier Studies, Exeter, 485-493.

Reddé (1996): Michel Reddé, “Un village dans les oasis d’Egypte: Douch”, in: Jean Peyras and Georges Tirologos (eds.), L'Afrique du Nord antique, cultures et paysages, Paris, 67-84.

Reddé (1999): Michel Reddé, "Sites militaires romains de l'oasis de Kharga", in: Bulletin de l'Institut français d'archéologie orientale 99, 377-396.

Reddé (2007): Michel Reddé, “'’occupation militaire tardive dans les oasis d’Égypte. L'exemple de Douch”, in: Ariel Lewin and Pietrina Pellegrini (eds.), The Late Roman Army in the Near East from Diocletian to the Arab Conquest (British Archaeological Reports 1717), Oxford, 421-429. Reddé et al. (2004): Michel Reddé et al., Kysis. Fouilles de l'IFAO à Douch (1985-1990), Cairo. 
Rossi (2000): Corinna Rossi, “Umm el-Dabadib, roman settlement in the Kharga Oasis. Description of the visible remains, with a note on 'Ayn Amur”, in: Mitteilungen des Deutschen Archäologischen Instituts 56, 235-252.

Rossi (2013): Corinna Rossi, "Controlling the borders of the empire. The distribution of Late-Roman 'forts' in the Kharga Oasis", in: Roger S. Bagnall, Paola Davoli, and Colin A. Hope (eds.), The Oasis Papers 6. Proceedings of the Sixth International Conference of the Dakhla Oasis Project (Dakhla Oasis Project Monograph 15), Oxford, 331-336.

Rossi/Ikram (2006): Corinna Rossi and Selima Ikram, “North Kharga Oasis Survey 2003. Preliminary report: Umm el-Dabadib”, in: Mitteilungen des Deutschen Archäologischen Instituts Kairo 62, 279-306.

Rossi/Ikram (2010): Corinna Rossi and Selima Ikram, "North Kharga Oasis Survey 2007. Preliminary Report: Ain Lebekha and Ain Amur", in: Mitteilungen des Deutschen Archäologischen Instituts Kairo 66, 235-242.

Rossi/Ikram (2013): Corinna Rossi and Selima Ikram, "Evidence of desert routes across northern Kharga (Egypt's Western Desert)”, in: Frank Förster and Heiko Riemer (eds.), Desert Road Archaeology in Ancient Egypt and Beyond (Africa Praehistorica 27), Cologne, 265-282.

Rossi/Magli (2019): Corinna Rossi and Giulio Magli, "Wind, sand and water. The orientation of the late Roman forts in the Kharga Oasis (Egyptian Western Desert)", in: G. Magli, A. C. González-García, J.B. Aviles and E. Antonello (eds.), Archeoastronomy in the Roman World, Cham, 153-166.

Rossi et al. (forthcoming): Corinna Rossi et al., "Greening the desert at the southern edge of the Empire. The irrigation system of the Late Roman site of Umm al-Dabadib (Kharga Oasis, Egypt)", in: Proceedings of the Mediterranean Forum on Water Sources, Matera, October 18-22, 2015.

Sampsell (2014): Bonnie M. Sampsell, The Geology of Egypt. A Traveler's Handbook, Cairo and New York.

Samsó (2007): Julio Samsó, “al-Fazārī”, in: Encyclopaedia of Islam³, 91-93.

Sánchez-Moreno Ellart (2013): Carlos Sánchez-Moreno Ellart, “Deportation”, in: Roger S. Bagnall et al. (eds.), The Encyclopedia of Ancient History, vol. IV, Oxford, 2038-2040.

Schacht (2003): Ilka Schacht, "A preliminary survey of ancient qanat systems of the northern Kharga Oasis", in: Mitteilungen des Deutschen Archäologischen Instituts Kairo 59, 411-423.

Schwartz (1966): Jacques Schwartz, "In Oasin relegare”, in: Raymond Chevallier (ed.), Mélanges d'archéologie et d'histoire offerts à André Piganiol (Ecole pratique des hautes études Section 6: Sciences économiques et sociales), Paris, 1481-1488.

Tallet et al. (2011): Gaëlle Tallet, Romain J. Garcier, and Jean-Paul Bravard, “L'eau perdue d'une micro-oasis. Premiers résultats d'une prospection archéologique et géoarchéologique du système d'irrigation d'El-Deir, oasis de Kharga (Égypte)", in: Catherine Abadie-Reynal et al. (eds.), Les réseaux d'eau courante dans l'Antiquité. Réparations, modifications, réutilisations, abandon, récupération. Actes de la Table ronde organisée à Université de Nancy, 20-21 Novembre 2009 (Archéologie et culture), Rennes, 178-180.

Tallet et al. (2012a): Gaëlle Tallet, Coralie Gradel, and Fleur Letellier-Willemin, “'Une laine bien plus douce que celle des moutons' à El-Deir (oasis de Kharga). Le coton au cœur de l'économie oasienne à l'époque romaine", in: Stéphanie Guédon (ed.), Entre Afrique et Égypte. Relations et échanges entre les espaces au sud de la Méditerranée à l'époque romaine (Ausonius publications 49), Limoges, 119-141.

Tallet et al. (2012b): Gaëlle Tallet, Coralie Gradel, and Stéphanie Guedon., "Le site d'El-Deir, à la croisée des routes du désert occidental. Nouvelles perspectives sur l'implantation de l'armée romaine dans le désert égyptien", in: Pascale Ballet (ed.), Grecs et Romains en Égypte. Territoires, espaces de la vie et de la mort, objets de prestige et du quotidien (Bibliothèque d'étude 157), Cairo, 75-92. 
Triaud (1999): Jean-Louis Triaud, “Le nom de Ghana. Mémoire en exil, mémoire importée, mémoire appropriée”, in: Jean-Pierre Chrétien and Jean-Louis Triaud (eds.), Histoire d'Afrique. Les enjeux de mémoire (Hommes et sociétés), Paris, 235-280.

Vallejo Girvés (2004): Margarita Vallejo Girvés, “Locus horribilis? El destierro en el Gran Oasis egipcio durante la Antigüedad Tardía”, in: Mustapha Khanoussi, Paola Ruggieri, and Cinzia Vismara (eds.), L'Africa Romana 15. Ai confini dell'Impero: contatti, scambi e conflitti. Atti del XV convegno di studio, Tozeur 11-15 dicembre 2002, Rome, 691-697.

Vivian (2000): Cassandra Vivian, The Western Desert of Egypt: An Explorer's Handbook, Cairo.

Wagner (1987): Guy Wagner, Les Oasis d'Égypte à l'époque grecque, romaine et byzantine d'après les documents grecs (Bibliothèque d'étude 100), Cairo.

Wipszycka (2009): Ewa Wipszycka, Moines et communautés monastiques en Égypte (IVe-VIII siècles) (Journal of Juristic Papyrology suppl. 11), Warsaw.

Wuttmann (2001): Michel Wuttmann, "Les qanats de 'Ayn-Manâwîr (oasis de Kharga, Egypte)”, in: Pierre Briant (ed.), Irrigation et drainage dans l'Antiquité, qanāts et canalisations souterraines en Iran, en Egypte et en Grèce. Séminaire tenu au Collège de France (Persika 2), Paris, $109-135$. 
